\title{
Effect of Tick and Lice on Some Blood Constitute and Trace elements of Local Black Goat in Sulaimani, Kurdistan Region of Iraq
}

\author{
Bawan Mustafa Abdalrahman \\ Animal Sciences \\ College of Agricultural Sciences \\ University of Sulaimani \\ Sulaymaniyah, Iraq \\ Bawan.abdalrahman@univsul.edu.iq
}

\author{
Bahzad Hama Salih Mustafa \\ Animal Sciences \\ College of Agricultural Sciences \\ University of Sulaimani \\ Sulaymaniyah, Iraq \\ Bahzad.mustafa@univsul.edu.iq
}

\begin{abstract}
In this study isolated 100 adult female of local black goat (Capra hircus) examined in spring and fall season for Tick and Lice investigations, then divided into two groups: 50 infested goats with ectoparasite and 50 non-infested goats. Three species of ticks (Rhipicephalus sanguinus, $R$. turanicus and $R$. bursa) and one species of lice (Bovicola caprae) were observed. Biochemical values (serum proteins and some trace elements) analyzed, in infested goats emerges decline in serum protein value $7.12 \pm 0.08$ $\mu \mathrm{g} / \mathrm{dl}$, albumin value $4.12 \pm 0.03 \mu \mathrm{g} / \mathrm{dl}$ and increase of globulin value $3.04 \pm 0.09 \mu \mathrm{g} / \mathrm{dl}$, in serum protein and globulin values shows not significance differences, while described highly significance differences in albumin value at $p \leq 0.01$, when compare to control goats. In trace elements decline of zinc level 48.97 \pm 1.20 $\mu \mathrm{g} / \mathrm{dl}$ and copper level 114.15 $\pm 3.75 \mu \mathrm{g} / \mathrm{dl}$ levels with a highly significant differences at $p \leq 0.01$ in infested goats when compare to control goats. It is observed that mixed infestation has much effects than tick or lice infestation on goats, which led to reduction in serum protein value $6.89 \pm 0.20 \mu \mathrm{g} / \mathrm{dl}$, albumin value $4.11 \pm 0.09$ $\mu \mathrm{g} / \mathrm{dl}$ and raise in globulin value $3.10 \pm 0.11 \mu \mathrm{g} / \mathrm{dl}$ without any significance differences, also noticed insignificant declines in zinc level $45.67 \pm 2.40 \mu \mathrm{g} / \mathrm{dl}$, while decrease in copper level $99.33 \pm 9.86 \mu \mathrm{g} / \mathrm{dl}$ significantly at $p \leq 0.05$.
\end{abstract}

Keywords: Goat, Tick, Lice, Blood constitute.

\section{INTRODUCTION}

Ectoparasites are most critical disorders and diseases, which encounter to animals; they led to lose in their productions and disturb animal health entirely. It may be accompanied by more disorders, deficiencies such as decrease in some blood biochemical parameters, blood trace elements and mineral levels, which are seems as a severe health problem in livestock [1]. Hypersensitivity, marked blood loss, secondary infestation, excoriation and ultimately death in few cases, whole of them related to ectoparasitisms, also indirect harm, rubbing and reducing time spent for grazing or rumination as increasing levels of behavior, self wounding in some cases, also referred to the influences of ectoparasites [2]. Tick and lices are involve of about $70 \%$ of ectoparasites that naturally infested goat According to [3]. An economical and short-day breeder of goat make of them an appropriate small ruminant to rearing, which are adaptable in the various ecological situations as like as pathological resistance [4]. Main challenges which exposed with Kurdistan region's livestock health and productivity, are ticks and tick-borne blood parasites disease [5]. Widely ectoparasites especially tick and lices, causes more lesion and disorders for livestock as blood loss, which is led to growth retards and loss of weight (ticks and sucking lices), irritation and discomfort in animal which is called tick worry also in lices, wound which is way of endoparasites and germs of entering to animal's body. Crusting, dermatitis and wool or skin debilitation, especially in chewing lices [6, 7]. One of the most vital parameters are blood biochemical constitutes which that through knowing of them can detect any disorder and infections in human and animals [8], common and important biochemical component is a serum protein and its differentials (albumin and globulin) which they are contribute in immunity, catalytic, regulation system and any imbalance or dysfunction of serum protein component led to emerges disease [9]. Trace elements are essential for maintain, healthy and productivity of each animals, some of the well known established (Fe, $\mathrm{Cu}, \mathrm{Zn}$, Co, Se among others) is fundamentally present in most biochemical operation, in animal living body and during any infection, serum trace element alters in their concentration [10]. Our objectives are to carrying out this study, to detect influences of these ectoparasites and also effects of the type of each ectoparasites on serum proteins and some trace elements (Zinc and Copper) of goat, with identifying the genera and species of these ectoparasites that presence in present study.

\section{METHODS AND MATERIALS}

2.1 Study Area: This study was conducted in Sulaimani Governorate, Kurdistan region. The samples were collected on the local black goats, during spring (April and May) and early fall (September) of 2018. 
2.2 Sampling: In this study, adult local black doe (Capra hircus) were examined for tick and lices, after investigation, infested goats $(n=50)$ were isolated from non-infested goat (control, $n=50$ ), whereas infested goat divided into three groups depend on types of the ectoparasite, as follows:

1- Tick infestation

2- Lice infestation

3- Mixed infestation (Tick and lices)

2.3 Collection of Ticks and Lice: tick and lice or mixed of them were collected from the suspected parts of the goats such as ears, teats, outers reproduction parts, breast, abdomen, mouth and under tails. In the process of tick collection, a fine and smooth forceps was used to remove the ticks with consideration to remain all parts of body healthy and not defected by mechanical pressure. In the lice collection, the procedure was done through brushing the hair of goat, and then lices were placed on a white paper or other like this. Finally tick and lices were collected and placed in the glass vials of $25 \mathrm{~mm}$ diameter and $75 \mathrm{~mm}$ long that contain $70 \%$ alcohol till examination.

2.4 Specimens' examination: The specimens were examined by using Motic digital microscopy 4X magnification., Motic educator, Japan, for studying the minute parts of the body, such as mouth parts, ornamentation, legs, body shape and to comparisons between species or in genus of arthropods according to [11].

2.5 Blood collection and examination: Blood was drawn from jugular vein with $10 \mathrm{ml}$ sterile syringe and 18 gauge needles (Hoshin medical instrument Co., Ltd, P.R.C). Blood are placed in the free anticoagulant tube and left to clot and then centrifuged at $3000 \mathrm{rpm}$ for 15 min (Hettich, zentrifugen, D-78532 Tuttlingen, Germany), and collected serum kept frozen at $-20^{\circ} \mathrm{C}$ until examined it [12].

2.6 Blood smear and fecal examination: Geimsa stained blood smear and fecal direct smear examined through Motic digital microscopy,40X, 60X and 100X, Motic educator, Japan., were carried out, to ensuring lack of any endoparasites in blood and feces, to avoid any interaction with ectoparasites effect in infested goat and to distinguish control goats with its each declines in their blood values.

2.7 Serum protein examination: Serum protein, albumin and globulin were determined by automatic BioLis 24i premium analyzer (Tokyo BOEKI MEDISYS INC. (CDiamond diagnostic $\left.{ }^{\circledR}\right)$. Determination in this apparatus, operation was carried out by Beer Lambert laws, globulin portion of serum protein was determined through the deduction of albumin portion from total serum protein: Serum protein - Albumin $=$ Globulin 2.8 Zinc and copper determination: Zinc and copper were determined manually by Spectrophotometer (PD303, APEL., co., Ltd. Japan). Specific commercial kits were used in both determinations. For zinc was used commercial kit (Colorimetric test with 5-Brom-PAPS, Egypt biotechnology co.), MDSS GmbH. Schiffgraben 41, 30175 Hannover, Germany, and its procedure run on, by preparing at first blank as (1ml of reagent and empty of standard and sample), standard as (1 $\mathrm{ml}$ of reagent, 50 $\mu \mathrm{l}$ of standard and empty of sample) and sample as (1ml of reagent, $50 \mu \mathrm{l}$ of sample and empty of standard), and using 560 nanometer wave length with turn apparatus on an absorbance reading, their records for blank is 0.076 and for standard is 0.295. Also for copper was used commercial kit (Egypt biotechnology co.), MDSS GmbH. Schiffgraben 41, 30175 Hannover, Germany, and its procedure ran on by preparing at first blank as (1ml of reagent and empty of standard and sample), standard as (1 ml of reagent, $66 \mu \mathrm{l}$ of standard and empty of sample) and sample as (1 $\mathrm{ml}$ of reagent, $66 \mu \mathrm{l}$ of sample and empty of standard), and using 580 nanometer wave length with turn apparatus on an absorbance reading, their records for blank is 0.081 and for standard is 0.243 .

2.9 Data Analysis: Data after rearrangement and designed in the table, were analyzed through $\mathrm{T}$. test independent sample and one way ANOVA uni-factor CRD and using both $(\mathrm{p} \leq 0.01)$ and $(\mathrm{p} \leq 0.05)$, analysis process carried out by SPSS program, release of 16.0.0 (sep. 13, 2007).

\section{RESULTS AND DISCUSSION}

As by examination in local goat, founds that there were two types of ectoparasite, which are hard ticks (Ixodidae) family and chewing lice (Mallophaga), through detection of important parts such as mouth parts and legs and presence of ornamentation in hard ticks, also head and body part and shapes in lice, were founds that, in hard ticks, that three species which are Rhipiciphalus sanguinus, Rhipicephalus turanicus and Rhipicephalus bursa, in lice one species of chewing type observed, which was Bovicola caprae as illustrated in the Table 1.

Table 1: Prevalence of ectoparasites on goat in Sulaimani.

\begin{tabular}{ccccc}
\hline Ectoparasites & \multicolumn{3}{c}{ Tick } & Lice \\
\hline \multirow{2}{*}{ Species } & $\begin{array}{c}R . \\
\text { turanicus }\end{array}$ & $\begin{array}{c}R . \\
\text { sanguinus }\end{array}$ & $\begin{array}{c}R . \\
\text { bursa }\end{array}$ & $\begin{array}{c}\text { B. } \\
\text { Caprae }\end{array}$ \\
\hline Number & 68 & 77 & 16 & 210 \\
\hline Total & & 161 & & 210 \\
\hline Percentage\% & 42.23 & 47.82 & 9.95 & 100 \\
\hline
\end{tabular}

In the ticks as founds there were three species of Rhipicephalus: $R$. sanguine (47.82\%), which is known a brown dog tick, also infested small ruminants especially animals that reared close to $\operatorname{dog}[13], R$. turanicus (42.23\%) and $R$. bursa (9.95\%) which is known as brown ear tick. Rhipicephalus spp refers to important genus of hard ticks, which are indicated through having short mouth parts, eyes and presence of festoons with hexagonal basis of capitulum, and absence of ornamentation on their backs as identified by [14]. These three species were mostly similar in their future, especially they have a dark scutum, U shaped genital aperture in female and short pedi palpus except of some differences as in fed male of $R$. bursa caudal appendage is absent or small while in $R$. sanguinus and $R$. turanicus are abroad and visible, genital aperture in female of $R$. turanicus is narrow but in $R$. sanguinus is abroad according to [11, 14]. In spring months as April and May $R$. sanguinus and $R$. turanicus were high prevalence while in Fall tick was absent generally as shows in our results, so its concur with results of the study which was observed that, Rhipicephalus spp is 
most frequently appear in the spring months in Sulaimani [15] as their environment are favorable for growth, activity, reproduction and development of ticks [16], also our results is agreed with [17] in SulaimaniKurdistan region in the infestation with $R$. sanguinus and [18] in Ilam province in Iran which they found that $R$. sanguinus is most prevalence tick on goat but in the distribution of percentage of $R$. bursa is contrast with results of this study as they said that this species distribution is $41.5 \%$ on goat and in another study also contrast with present study as they said that $89 \%$ of goat in Urmia, Iran are infested with $R$. bursa [19], also the present study is agreed with the observation of [3] in Duhok-Kurdistan region, which founds that $R$. turanicus and $R$. sanguinus are most prevalence species on goat by $45.54 \%$ and $33.93 \%$ respectively. Present study is agreed with another examination by some researcher which mentioned in their works that Rhipicephalus spp is appeared after rainy seasons, as spring season and also agree with their states of some researchers which mentioned that they are not founds any other genera especially Hyalomma spp. and Haemaphysalis spp in their works [19]. Lice examination in both mentioned season shows, that Bovicola caprae is most prevalence on goat while in autumn is less than in spring and might be due to in spring these animal are not shorn yet, in contrast to autumn, [19] Urmia in Iran and [17] in Sulaimani in Kurdistan region-Iraq, they founds in that Bovicola caprae is most prevalence lice on the goat with $71.4 \%$ which is like to our observation, also is agree with result of the study in Duhok in Kurdistan region, which pointed that Bovicola caprae is most distributed on local goat by $80.7 \%$ [3].

In the results variance between infested and control animal and also between individual effect of each ectoparasite in about of biochemical values (Serum protein, albumin, globulin, Zinc and Copper) were determined and illustrated in (Table 2\&3).

Table 2: Effects of ectoparasites on Serum protein and some

\begin{tabular}{|c|c|c|}
\hline Parameters & $\begin{array}{l}\text { Non Infested } \\
\text { C.I (95\%) } \\
\end{array}$ & $\begin{array}{c}\text { Infested } \\
\text { C.I (95\%) } \\
\end{array}$ \\
\hline $\begin{array}{c}\text { S. Protein } \\
(\mu \mathrm{g} / \mathrm{dl})\end{array}$ & $\begin{array}{l}7.32 \pm 0.07 \\
(7.17-7.46)\end{array}$ & $\begin{array}{l}7.12 \pm 0.08 \\
(6.94-7.29) \\
\end{array}$ \\
\hline Albumin ( $\mu \mathrm{g} / \mathrm{dl})$ & $\begin{array}{c}4.34 \pm 0.04 \\
(4.25-4.44) \\
\end{array}$ & $\begin{array}{c}4.12 \pm 0.03^{* *} \\
(4.04-4.20) \\
\end{array}$ \\
\hline Globulin ( $\mu \mathrm{g} / \mathrm{dl})$ & $\begin{array}{l}2.97 \pm 0.08 \\
(2.80-3.13) \\
\end{array}$ & $\begin{array}{c}3.04 \pm 0.09 \\
(2.84-3.23) \\
\end{array}$ \\
\hline Zinc ( $\mu$ g/dl) & $\begin{array}{c}57.21 \pm 1.96 \\
(53.25-61.16)\end{array}$ & $\begin{array}{l}48.97 \pm 1.20 * * \\
(46.54-51.39)\end{array}$ \\
\hline Copper ( $\mu \mathrm{g} / \mathrm{dl})$ & $\begin{array}{c}127.02 \pm 2.35 \\
(122.29-131.76)\end{array}$ & $\begin{array}{c}114.15 \pm 3.75^{* *} \\
(106.60-121.71)\end{array}$ \\
\hline
\end{tabular}

Despite that these values are declined slightly about to reference values but they having differences according to their situation which are in serum protein value $(7.12 \pm 0.08 \mu \mathrm{g} / \mathrm{dl})$ of infested goat shown decreases and globulin value increases $(3.04 \pm 0.09 \mu \mathrm{g} / \mathrm{dl})$ but not enough to make any differences $(\mathrm{p} \geq 0.05)$ while albumin value $(4.12 \pm 0.03 \mu \mathrm{g} / \mathrm{dl})$ emerges reduction statistically $(\mathrm{p} \leq 0.01)$ in naturally infested goat with compare to control goat. In $\mathrm{Zn}$ and $\mathrm{Cu}$, infested goats shows decrease in their levels $(48.97 \pm 1.20 \mu \mathrm{g} / \mathrm{dl}$ and
$114.15 \pm 3.75 \mu \mathrm{g} / \mathrm{dl}$ ) sequentially and variation in their levels enough to make highly significance differences $(\mathrm{p} \leq 0.01)$ as compare to non infested goat.

Table 3: Effects of tick, lice and mixed of them on serum protein and some trace elements.

\begin{tabular}{|c|c|c|c|}
\hline Parameters & $\begin{array}{c}\text { Tick } \\
\text { C.I (95\%) } \\
\end{array}$ & $\begin{array}{c}\text { Lice } \\
\text { C.I (95\%) } \\
\end{array}$ & $\begin{array}{c}\text { Mix } \\
\text { C.I (95\%) } \\
\end{array}$ \\
\hline $\begin{array}{l}\text { S. Protein } \\
(\mu \mathrm{g} / \mathrm{dl})\end{array}$ & $\begin{array}{c}7.10 \pm 0.19 \\
(6.68-7.52)\end{array}$ & $\begin{array}{c}7.22 \pm 0.11 \\
(6.99-7.45)\end{array}$ & $\begin{array}{c}6.89 \pm 0.20 \\
(6.44-7.34)\end{array}$ \\
\hline $\begin{array}{c}\text { Albumin } \\
(\mu \mathrm{g} / \mathrm{dl})\end{array}$ & $\begin{array}{c}4.11 \pm 0.05 \\
(4.01-4.22)\end{array}$ & $\begin{array}{c}4.13 \pm 0.08 \\
(3.94-4.32)\end{array}$ & $\begin{array}{c}4.11 \pm 0.09 \\
(3.89-4.33)\end{array}$ \\
\hline $\begin{array}{c}\text { Globulin } \\
\text { ( } \mu \mathrm{g} / \mathrm{dl})\end{array}$ & $\begin{array}{c}2.97 \pm 0.20 \\
(2.52-3.42)\end{array}$ & $\begin{array}{c}2.95 \pm 0.28 \\
(2.31-3.60)\end{array}$ & $\begin{array}{c}3.10 \pm 0.11 \\
(2.87-3.33)\end{array}$ \\
\hline $\begin{array}{l}\text { Zinc } \\
(\mu \mathrm{g} / \mathrm{dl})\end{array}$ & $\begin{array}{c}48.89 \pm 1.29 \\
(46.24-51.55)\end{array}$ & $\begin{array}{c}52.74 \pm 3.49 \\
(44.95-60.53)\end{array}$ & $\begin{array}{c}45.67 \pm 2.40 \\
(40.38-50.96)\end{array}$ \\
\hline $\begin{array}{l}\text { Copper } \\
\text { ( } \mu g / d l)\end{array}$ & $\begin{array}{c}110.48 \pm 8.90^{\mathrm{a}} \\
(90.89-130.07)\end{array}$ & $\begin{array}{c}121.82 \pm 3.63^{\mathrm{a}} \\
(114.35-129.30)\end{array}$ & $\begin{array}{c}99.33 \pm 9.86^{\mathrm{b}} \\
(106.60-121.71)\end{array}$ \\
\hline
\end{tabular}

(Different letters are signs to presence differences significantly at $\mathrm{p} \leq 0.05)$.

Goat which naturally infested with mixed (Tick and Lice) ectoparasite at the same time, shown decrease in value of serum protein $(6.89 \pm 0.20 \mu \mathrm{g} / \mathrm{dl})$, albumin value $(4.11 \pm 0.09 \mu \mathrm{g} / \mathrm{dl})$ with increases in serum globulin value $(3.10 \pm 0.11 \mu \mathrm{g} / \mathrm{dl})$, with compare to goat which infested only with tick or merely with lice, but without any statistical differences $(p \geq 0.05)$ among them. In the previous table that, goat which naturally infested with mixed ectoparasite (tick and lices) at the same time, shows decrease in $\mathrm{Zn}(45.67 \pm 2.40 \mu \mathrm{g} / \mathrm{dl})$ and $\mathrm{Cu}$ $(99.33 \pm 9.86 \mu \mathrm{g} / \mathrm{dl})$ levels, with comparing to goat which infested only with tick or merely with lice, but without any significance differences ( $\mathrm{p} \geq 0.05$ ) in $\mathrm{Zn}$ among them, while in $\mathrm{Cu}$ has significance differences $(\mathrm{p} \leq 0.05)$ when comparing to their values in goat which infested with only ones of these ectoparasite. These results are contrast to result of the study which is done by $[20,21]$ as they stated in their study, were serum protein is increased significantly $(\mathrm{p} \leq 0.05)$ and $(\mathrm{p} \leq 0.01)$ respectively, while the present results have supporting by some results of the same study as albumin decreased with highly significance differences $(\mathrm{p} \leq 0.05)$ and $(\mathrm{p} \leq 0.01)$ respectively and increases of globulin in goat and sheep infested with ectoparasite, with a compare to control group. Present study in agreement with [22] as they showed decrease of serum protein and significance decrease $(p \leq 0.05)$ of albumin in infested goat, as compare to control goats while our results not agreed with decline globulin as in this study mentioned, also is contrast to observation of [17] as they detect of serum globulin decreased. The present study is agreed with its reached by [1] in infested sheep and [4] in the infested goat, as they said that, serum protein and albumin decreased and globulin increased significantly $(\mathrm{p} \leq 0.05)$ but in our results is not significantly $(\mathrm{p} \geq 0.05)$ in serum protein and globulin. As [21] were stated that, increases of serum globulin is a sign of development response of antibody to antigen presence in the area. Decrease of albumin and serum protein might be also related to malnutrition as [22] they emphasis in their work, also as [1] illustrated in his investigation that decrease of serum 
protein might feature of increasing blood cortisol in an infected animal, hence some clues said that elevation of cortisol led to protein catabolism and then nitrogen imbalance, ultimately increases secretion of nitrogen through the urinary tract, while as [17] stated that decrease of serum protein and its differentials might be related to liver dysfunction as a primary and secondary impact of parasites as diarrhea, fever and loss of appetite.

In the Measureable reduction of zinc and copper in the infested goat statistically $(\mathrm{p} \leq 0.01)$ in compares with control goats, the present study is parallel to which it reached by [1] in high zinc decreased $(\mathrm{p} \leq 0.01)$ in infested sheep with compare to non infested sheep in Sulaimani and also agree with the same cached result by [10] in the diseased animal. Also the present study is absolutely concur to [23] was observed highly decreased in $\mathrm{Zn}$ and $\mathrm{Cu}$, statistically $(\mathrm{p} \leq 0.01)$ in infected sheep, also agree with [24] as they detected significance differences $(\mathrm{p} \leq 0.05)$ in some trace elements particularly in $\mathrm{Zn}$, in infested goats, while our results are vary to [25] as they observed, increase of $\mathrm{Cu}$ with significance differences $(\mathrm{p} \leq 0.05)$ and decreases of $\mathrm{Zn}$ without any significances $(p \geq 0.05)$ in diseased sera in comparing with healthy sera. As in the Table 3 was illustrated, in all results, influence of lice is less than both mixed infestation and tick infested goat, this result have agreement with [17] but with varying in serum protein as in their study effect of lice are more on this parameter than ticks, except of copper whole other parameters (serum proteins and zinc) has not any differences ( $\mathrm{p} \geq 0.05$ ) among them. This variation of effects and minimal impact of lice might be related to its types as in this study merely present on genus of chewing lice Bovicola caprae and also its not sucking blood, mainly has secondary effects on blood parameters as [26] pointed in their study. Reduction of zinc concentration also can seen as hepatic disorders as [27] stated that, also as mentioned in FAO and WHO [28] that 70\% of Zn and $\mathrm{Cu}$ are bound with albumin and any alteration of albumin as in this study showed statistically remarkable decreased $(\mathrm{p} \leq 0.01)$ in infested goat, led to decrease of these trace elements as a secondary infestation. Zn declined might be reverses to immune response for any infections [10]. Nutrition and especially in animal which fed on natural pasture and grazing are the most factors to fluctuating trace element in the animal blood as [1] is mentioned in his research that low content of each trace element in pasture might be predisposing the factor to decrease its concentration in animal, also alkaloid soil or $\mathrm{PH}$ above 6.5 makes obstacle to absorption of $\mathrm{Zn}, \mathrm{Cu}$ and some other elements by the plant and ultimately low concentration in serum of animal. Forage plants which increase in calcium concentration is another factor to decrease in the some trace element especially in $\mathrm{Zn}$. Interaction as cooperation and antagonism between elements are major factors to imbalance and deficiency of any of them in animal blood, as Mustafa [1] that high calcium or high calcium-phosphorus intake led to less absorption of Zn. Decrease of trace element in control animals might be due to mal absorption or as [29] and [23] mentioned that is due to animals are not benefit of trace element in their feeding and water, and also cadmium, molybdenum or any heavy metals can limit of absorption and normal concentration of any trace element especially $\mathrm{Cu}, \mathrm{Fe}$ and $\mathrm{Zn}$ or interaction in them as level of cobalt and $\mathrm{Cu}$, cadmium, manganese limit of Fe absorption.

\section{CONCLUSION}

In this study that Rhipicephalus spp and Bovicola caprae were most prevalence on goat in Sulaimani-Kurdistan region of Iraq. Also present study shows marked impacts of ectoparasites on the biochemical values of local goat. Mixed infestation and tick infested goat were mostly affected than infestation of lice and it might be related to the type of lice. More investigation required to detecting ectoparasites effect on another trace element and biochemical parameters, also in various periods or twice as early and late infestation, for this purpose animal tagging (numbering) is required.

\section{REFERENCES}

[1] B. Mustafa, "Level of zinc and some blood phenomena in sheep infested naturally with hard tick (Ixodidae) in Sulaimani province-Iraq," Al-Anbar J. Vet. Sci. , vol. 6, 2013.

[2] W. M. Ahmed, S. M. Habeeb, F. M. E. Moghazy, and E. M. Hanafi, "Observation on Pediculosis in Buffalo-Cows with Emphasis on its Impact on Ovarian Activity and Control by Herbal Remedies," World Applied Sciences Journal vol. 6, pp. 1128-1138, 2009.

[3] I. K. Zangana, B. A. Ali, and I. A. Naqid, "DISTRIBUTION OF ECTOPARASITES INFESTED SHEEP AND GOATS IN DUHOK PROVINCE, NORTH IRAQ.," Bas.J.Vet.Res., vol. 12, 2013.

[4] P. Sahu and S. Gaherwal, "Biochemical Changes in Ticks Infected Goats (Capra hircus) in Mhow Region," International Journal of Science and Research (IJSR), vol. 5, 2016.

[5] S. Renneker, J. Abdo, M. A. Bakheit, B. Kullmann, D. Beyer, J. Ahmed, et al., "Coinfection of Sheep with Anaplasma, Theileria and Babesia Species in the Kurdistan Region, Iraq," Blackwell Verlag GmbH • Transboundary and Emerging Diseases, vol. 60, pp. 113-118, 2013.

[6] DAIS, "The effects of ticks on animals," ed. Pretoria, South Africa Directorate Agricultural Information Services,Department of Agriculture, 2008.

[7] M. Rahman, "Investigation of Caprine Ectoparasitic Infestations in Southern Districts of Bangladesh," CHITTAGONG VETERINARY AND ANIMAL SCIENCES UNIVERSITY2014.

[8] I. Z. Bani, A. Al-Majali, F. Amireh, and O. Al-Rawashdeh, "Metabolic profiles in goat does in late pregnancy with and without subclinical pregnancy toxemia," Veterinary clinical pathology, vol. 37, pp. 434-437, 2008.

[9] R. Pieper, C. L. Gatlin, A. J. Makusky, P. S. Russo, C. R. Schatz, S. S. Miller, et al., "The human serum proteome: Display of nearly 3700 chromatographically separated protein spots on two-dimensional electrophoresis gels and identification of 325 distinct proteins," Proteomics, vol. 3, pp. 1345-1364, 2003.

[10] M. M. H. Mohammed, M. M. A. A. Makoush, N. A. A. A. Mohammed, R. A. O. Ahamed, R. D. A. M. Aibed, and T. F. A. O. Ahamed, "A Study of Some Trace Minerals Status in Serum of Sick Animals," Sudan University of Science and Technology, 2016.

[11] A. R. Walker, A. Bouattour, J.-L. Camicas, A. Estrada-Peña, I. G. Horak, A. A. Latif, et al., Ticks of domestic animals in Africa: a guide to identification of species: Bioscience Reports Edinburgh, 2003.

[12] S. Al-Bulushi, T. Shawaf, and A. Al-Hasani, "Some hematological and biochemical parameters of different goat breeds in Sultanate of Oman "A preliminary study"," Veterinary World, vol. 10, pp. 461-466, 04/30 01/04/received 03/21/accepted 2017.

[13] C. d. Matos, "Species composition and geographic distribution of ticks infesting cattle, goats and dogs in Maputo Province, Mozambique," Department of Veterinary Tropical Diseases, 
Faculty of Veterinary Science, University of Pretoria, University of pretoria, 2008.

[14] w. Richard. Bristol University Tick ID, Online photographic guide to ticks [Online]. Available: http://www.bristoluniversitytickid.uk/

[15] B. H. S. Mustafa, "Study on some epidemiological factors of hard tick (ixodidae) in sheep in Sulaimani province/Kurdistan region-Iraq with trial to immunize rabbits against larval extract of Hyalomma anatolicum anatolicum," Ph.D dissertation, 2011.

[16] M. A. Kadir, I. K. Zangana, and B. H. S. Mustafa, "A study on epidemiology of hard tick (Ixodidae) in sheep in Sulaimani governorate - Iraq," Iraqi Journal of Veterinary Sciences, Supplement III, Proceedings of the 6th Scientific Conference, College of Veterinary Medicine, University of Mosul, vol. 26, pp. 95-103, 2012.

[17] R. M. Hassan, A. A. Essa, and B. H. S. Mustafa, "Influence of two species of Ticks and Lice on some hematological parameters in black goats during spring and summer seasons in Sulaimani Governorate - Kurdistan region.," Tikrit applied science journal, vol. 21, 2016.

[18] A. L. Monfared, M. Mahmoodi, and R. Fattahi, "Prevalence of ixodid ticks on cattle, sheep and goats in Ilam County, Ilam Province, Iran," Journal of parasitic diseases, vol. 39, pp. 3740, 2015.

[19] M. Yakhchali and A. Hosseine, "Prevalence and ectoparasites fauna of sheep and goats flocks in Urmia suburb, Iran," Veterinarski arhiv, vol. 76, pp. 431-442, 2006.

[20] K. Arvind, V. Vihan, and H. Sharma, "Haematological and biochemical effects of tick infestation in common Indian goat," Advances in Bio Research, vol. 1, pp. 163-168, 2010.

[21] G. Gökçe and Ş. Kizil Tepe, "Alterations in haematological and biochemical parameters in Morkaraman sheep with natural Psoroptes ovis infestation," Kafkas Univ Vet Fak Derg, vol. 19, pp. 975-978, 2013.

[22] N. U. Khan, M. Shafee, J. A. Khan, K. Ashraf, R. Khan, A. Khan, et al., "Sero-epidemiological study of ecto-and endoparasites and their hematological effects in small ruminants reared under pastoral system in district Bannu, Pakistan," Pure and Applied Biology, vol. 4, p. 50, 2015.

[23] A. A. Hatem, "Field and laboratory study of trace elements deficiency in sheep in Al-Najaf province," مجلة الكوفة للعلوم الطبية Kufa Journal For Veterinary Medical Sciences, vol. 6, 2016.

[24] E. Rakhshandehroo, S. M. Razavi, and S. Nazifi, "Experimental caprine coccidiosis: the pattern of changes in antioxidant micronutrients and vitamins," Veterinary Science Development, vol. 4, 2014.

[25] K. Seyrek, S. Pașa, F. Kıral, A. Bildik, C. Babür, and S. Kılıç, "Levels of zinc, copper and magnesium in sheep with toxoplasmosis," Uludag Univ J Fac Vet Med, vol. 23, pp. 1-2, 2004.

[26] A. Tadie, G. Terefe, and Y. Gizaw, "Hematological Profile of Sheep Experimentally Infested with Bovicola ovis," Vet Sci Technol, vol. 9, 2018.

[27] Y. Takuma, K. Nouso, Y. Makino, M. Hayashi, and H. Takahashi, "Clinical trial: oral zinc in hepatic encephalopathy," Alimentary pharmacology \& therapeutics, vol. 32, pp. 1080-1090, 2010.

[28] FAO and WHO, "Vitamin and mineral requirements in human nutrition," 2005.

[29] M. E. Or, A. Kayar, A. Kiziler, C. Parkan, R. Gonul, B. Barutçu, et al., "Determination of levels of some essential (iron, copper, zinc) and toxic (lead, cadmium) metals in the blood of sheep and in samples of water, plants and soil in Northwest Turkey," Veterinarski arhiv, vol. 75, p. 359, 2005. 